\title{
In Memoriam: \\ Anatol "Ted" Balbach, 1927-2007
}

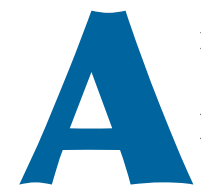

natol "Ted" Balbach, who served as director of research at the Federal Reserve Bank of St. Louis between 1975 and 1992, died in St. Louis on December 1, 2007.

Bank president William Poole came to know Ted and his wife, Rae, during the 1970s: "Ted continued and strengthened the St. Louis Fed research tradition developed and nurtured by Homer Jones, and Ted's leadership helped to establish the Homer Jones Memorial Lecture in 1987. Ted and Rae were especially gracious to my wife, Gerie, and me when we arrived in St. Louis in 1998, and, over the years since, the four of us enjoyed many good meals together. Ted's passing is a personal loss to me, as well as a professional one."

Balbach was born in Lithuania on October 31, 1927, and arrived in the United States with his mother in 1948 after World War II. From 1955 to 1957 , he served in the U.S. Army and subsequently finished his doctorate in economics at the University of California-Los Angeles. He taught for 15 years at California State UniversityNorthridge.

In 1971, Balbach joined the Bank's Research department as a visiting scholar and became a staff member in 1973. He became director of research in 1975. During his tenure, Balbach fostered contacts with central banks around the world, and numerous economists from Europe, Asia, and South America spent year-long exchanges at the St. Louis Fed.

Current research director Bob Rasche met Balbach when the two were visiting scholars at

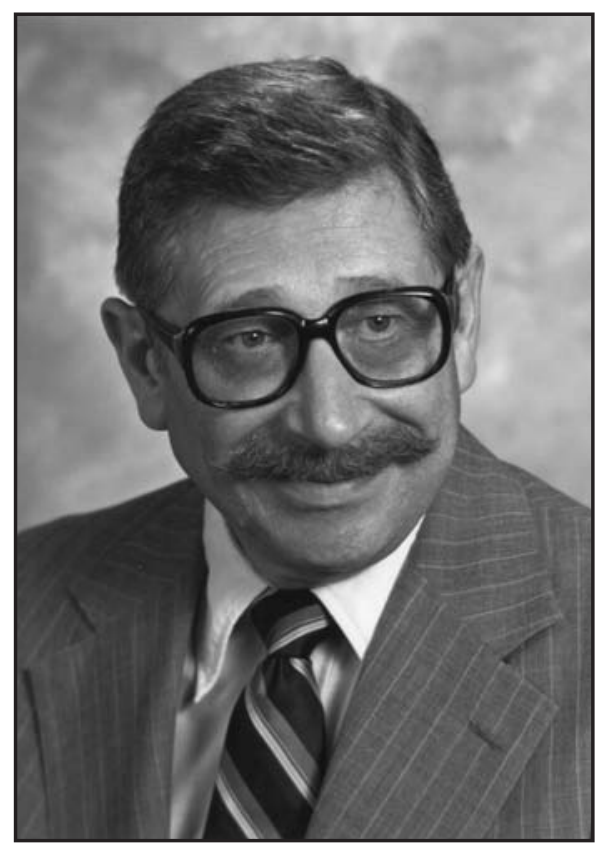

the Bank in the early 1970s: "Ted was the principal economic advisor to the Bank's president when the Great Inflation took place. At that time, the St. Louis Fed was one of the few, if not the only, Bank on the FOMC arguing for low and stable inflation-and arguing that the Fed must be the agent through which low and stable inflation would be achieved. He provided key support while the Fed brought inflation under control."

Following his retirement, Balbach consulted for Fiduciary Asset Management Co. He is survived by his wife of 49 years, Rachel (Rae), and sons Bruce and Adam.

Federal Reserve Bank of St. Louis Review, March/April 2008, 90(2), p. 63.

(C) 2008, The Federal Reserve Bank of St. Louis. Articles may be reprinted, reproduced, published, distributed, displayed, and transmitted in their entirety if copyright notice, author name(s), and full citation are included. Abstracts, synopses, and other derivative works may be made only with prior written permission of the Federal Reserve Bank of St. Louis. 
